\title{
The Effect of Gamma Radiation on the Shear Bond Strength of Flowable Self-Adhesive Resin Composite
}

\author{
Hazem Hussein Kazem", Eman Ali Abouauf ${ }^{2}$ \\ ${ }^{1}$ Health Research Department, National Center for Radiation Research \& Technology, \\ Atomic Energy Authority and ${ }^{2}$ Conservative Dentistry Department, Faculty of \\ Dentistry, Cairo University, Cairo, Egypt.
}

$\mathbf{T}$

HIS study is designed to investigate the influence of exposure to therapeutic gamma radiation on a self adhesive resin (Vertise-Flow). Twenty freshly extracted human molars were selected and used in the study. All the sound molars were examined and confirmed free of any cracks or defects. Standardized twenty discs were prepared from the selected molars of $2 \mathrm{~mm}$ thickness, then a hole of $3 \mathrm{~mm}$ diameter was prepared in each disc. The twenty holes prepared were restored with Vertise-Flow according to the manufacturer's instructions. Ten discs were randomly selected and subjected to an exposure dose of gamma radiation simulating the treatment dose delivered to the cancer patients, while the remaining discs were kept as control. Each sample was tested by a compressive loading via computer controlled materials testing machine, with a load of $5 \mathrm{KN}$. The maximum failure loading was reported in $\mathrm{N}$, while the shear bond strength (SBS) was calculated in MPa. It was found that the SBS of selfadhesive resins were reduced upon exposure to the therapeutic dose of gamma radiation. Yet, the difference was not statistically significant. Using simplified resin restorations as the selfadhesive composite restorations could be an efficient and easy restorative for patients receiving gamma radiotherapy.

Keywords: Self-adhesive resin, Shear bond strength, Gamma ray.

\section{Introduction}

Gamma radiation is utilized as a common method for treatment of some specific carcinomas in the head and neck. One of the most common external radiation sources is the Cobalt 60 that emits gamma rays, despite the fact there are some other heavy metals that could be also used to produce greater radiation energy (Toljanic \& Saunders, 1984). Carcinomas of the head and neck could be considered of high incidence as could represent $3 \%$ of the yearly reported cancer cases (Strong et al, 1986).

Patients who receive radiotherapy are subjected to psychological stress conditions that might induce xerostomia, other alterations in the normal oral environment conditions could result in developing multiple carious lesions known as radiation caries. The condition is expressed in a rampant dental decay that could develop within one year of therapy (Toljanic \& Saunders, 1984). A successful method to restore such carious lesions could be the adhesive tooth colored restorations; it is a simple and esthetic method that might satisfy the patient considering the appearance as well as tolerance to the operative and restorative procedures. Patients receiving radiotherapy are already exhausted due to a long and tiring treatment program of such assaulting disease and direct resin composite restorations could be considered one of the most successful tooth colored materials. However, the etching step followed by the adhesive application to the tooth structure could be time consuming and technique sensitive steps to some clinicians. Therefore, some manufacturers developed a selfadhesive resin composite restorative material as a solution to such irritating and time consuming sequence. Moreover, flowable composites offered the advantage of favorable handling properties due to the lower viscosity (Xie et al., 2008).

Radiation therapy was proved to alter the microstructure and the mechanical properties of the permanent human teeth (Guenka et al., 2014). Also, it was proved to alter some mechanical properties of tooth colored restoratives (ElMaghraby et al., 2005). Likewise, this could

"Corresponding author email: hazem_kazem@hotmail.com

DOI :10.21608/ejrsa.2018.1784.1020

(C)2017 National Information and Documentation Center (NIDOC) 
influence the adhesion and bond integrity of the recent adhesive restorative materials. The exposure to gamma radiation was proved to induce a detrimental effect on the bond strength to human enamel and dentin when the adhesive restoration was performed after radiotherapy (Naves et al., 2012). Yet, this study aim to investigate the influence of therapeutic gamma radiation on the restored teeth with adhesive restorations in relation to the SBS and to justify the use of such material for patients receiving radiotherapy.

\section{Materials and Methods}

Twenty freshly extracted human molars were selected to be used in the present study, provided that the selected teeth were free of any cracks or carious lesion as well as any structural defect. The molars were thoroughly washed, scaled to remove any calculus or soft tissues residues adhering to the root surface. The teeth were stored in distilled water at room temperature until use. Teeth were embedded in chemical cured acrylic resin and then cross-sectioned using IsoMet 4000 microsaw Buehler USA mounting diamond disk $0.6 \mathrm{~mm}$ thickness at speed $2500 \mathrm{rpm}$ and feeding rate $10 \mathrm{~mm} / \mathrm{min}$ under water cooling. The teeth were sectioned horizontally just below the dentinoenamel junction, until there was no enamel remained. Then another section was performed to cut a $2 \mathrm{~mm}$ thick disc. The thickness of the obtained discs was re-checked with a digital micrometer gauge. A cylindrical hole of $3 \mathrm{~mm}$ was prepared in each disc. The hole in each dentin disc was restored with flowable self-adhesive resin composite (Vertise-Flow) as follows: The disc specimens were placed on a celluloid matrix strip overlying a glass slab, then the material was injected into the prepared hole and adapted to the walls of the preparation using a plastic instrument. The restored dentin discs were covered with celluloid strip and a glass slab and light cured for $20 \mathrm{sec}$ at zero distance from the surface. Apical and coronal aspects of each sample were photographed and examined using stereomicroscope (Nikon MA100 Japan) to confirm absence of dentin cracks or voids of the filling materials. Material used in the study is listed in Table 1

\section{Grouping of the specimens}

The specimens were divided into two equal groups of ten each; one test group was subjected to an exposure dose of fractionated gamma radiation at a dose of $60 \mathrm{~Gy}$, three times a week (day after day) for one week (20Gy/3fractions/week). The irradiation was performed at the National Center of Radiation Research and Technology (NCRRT), Atomic Energy Authority, Cairo, Egypt, using Cesium-137 Gamma Cell 40 at a dose rate of 0.912 Gray/minute. The other test group was kept as a control.

TABLE 1. The material used in the study.

\begin{tabular}{|c|c|c|c|}
\hline $\begin{array}{l}\text { Material } \\
\text { used }\end{array}$ & $\begin{array}{c}\text { Commercial } \\
\text { name }\end{array}$ & Composition & Manufacturer \\
\hline \multicolumn{4}{|c|}{ Self- } \\
\hline adhesive & & GPDM; & \\
\hline resin & Vertise Flow & HEMA, & Kerr, Orange, \\
\hline \multicolumn{4}{|l|}{ CA, USA } \\
\hline & & Filler $(20 \mu \mathrm{m})$, & \\
\hline \multirow[t]{15}{*}{ Composite } & & barium glass & \\
\hline & & filler. & \\
\hline & & $(0.7-1 \mu \mathrm{m})$ & \\
\hline & & nano-sized & \\
\hline & & colloidal. & \\
\hline & & Silica (10- & \\
\hline & & 40nm), nano- & \\
\hline & & sized. & \\
\hline & & Ytterbium & \\
\hline & & fluoride & \\
\hline & & (40nm). & \\
\hline & & Zinc-oxide & \\
\hline & & pH:1.9. & \\
\hline & & $70 \mathrm{wt} \%$ filler & \\
\hline & & content. & \\
\hline
\end{tabular}

Shear bond strength test

The filling material was then loaded with a $0.9 \mathrm{~mm}$ diameter stainless steel plunger. The plunger was mounted on the upper part of a universal testing machine (Instron universal testing machine model 3354 England data recorded using computer software Bluehill 3 version 3.3). The samples were aligned over a support jig in an apical to coronal direction to avoid any constriction interference. The tests were conducted at a cross head speed of $0.5 \mathrm{~min}^{-1}$ using a $500 \mathrm{~N}$ load cell. The highest value recorded was taken as the pushout bond strength. The maximum failure load was recorded in $\mathrm{N}$, the failure was manifested by extrusion of the restoration and confirmed by the sudden drop recorded along the load deflection curve by the computer software (Fig. 1).

The shear bond strength was calculated from the recorded peak load divided by the computed surface area of the specimen and calculated as follows: 
The area under load was calculated $(A)=\pi$.d.t .

where $\pi=$ constsnt equals 3.14 , d: diameter of the specimen and $\mathrm{t}$ : thickness of the specimen. The push-out value in MPa was calculated from force (N) divided by area in $\mathrm{mm}^{2}$. Therefore, the shear bond strength $=\mathrm{F} / \mathrm{A}$

\section{Statistical analysis}

The result of the study was tabulated and statistically analyzed using computer software named the Statistical Package for Social Science (SPSS version 16). Data in the present study were presented as mean and standard deviation (SD). A comparison between the 2 study groups was performed with independent samples student t-test, at a level of $5 \%$ significance.

\section{$\underline{\text { Results }}$}

The maximum load applied to the specimens was recorded in Newton (Fig. 2 and 3) and the calculated shear bond strength was reported as MPa. (Table 2). The Mean shear bond strength values $(\mathrm{MPa})$ among the study groups are listed in Table 3. The independent samples student- $t$ test revealed that there was a drop in the shear bond strength when the irradiated specimens were compared to the control group. Yet, the difference was not statistically significant.

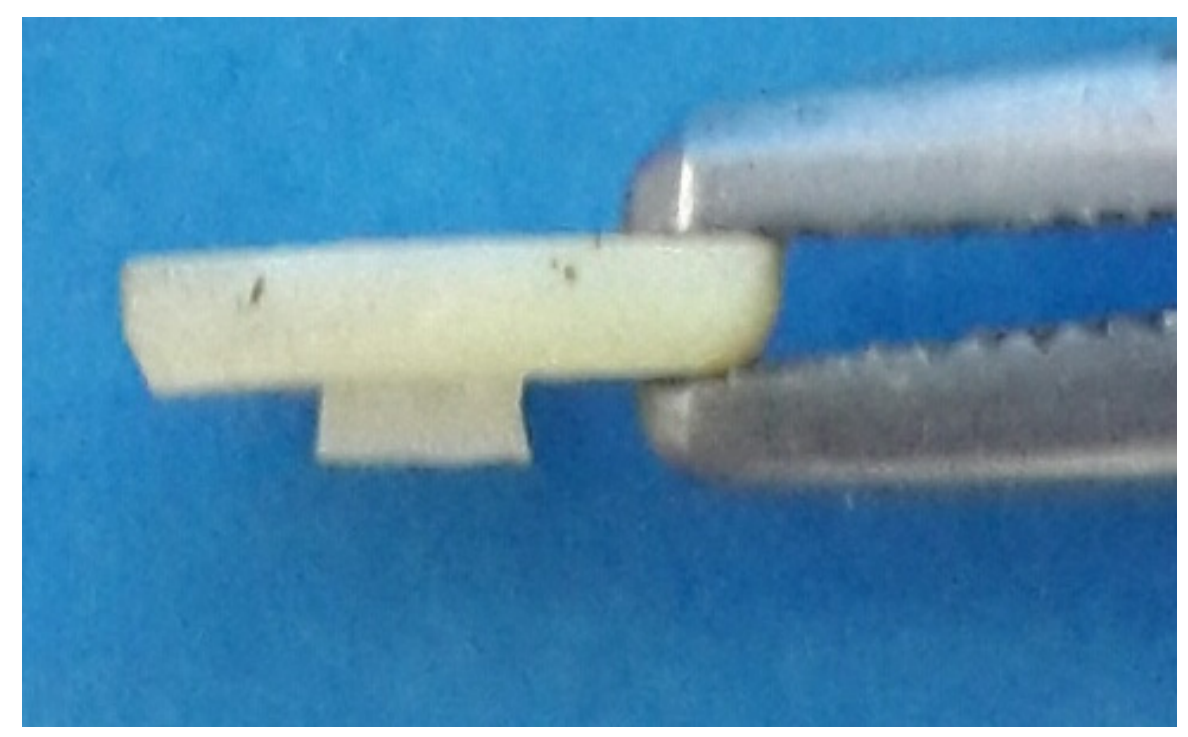

Fig. 1. The failure reported on extrusion of the restoration from the prepared specimen.
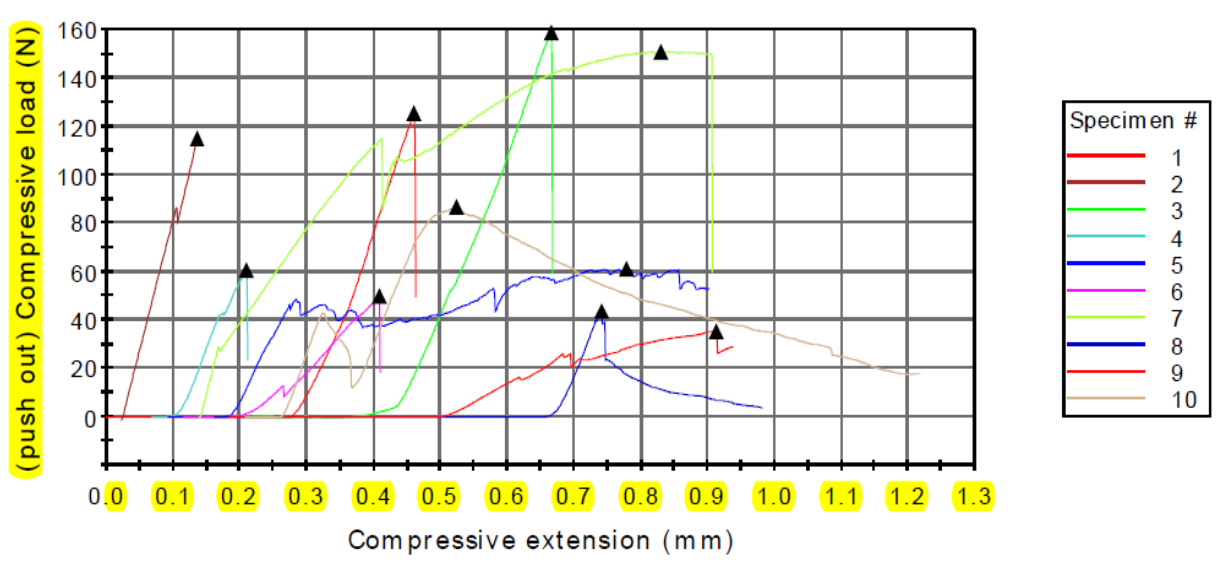

Fig. 2. Maximum load applied on the samples exposed to radiation (N). 

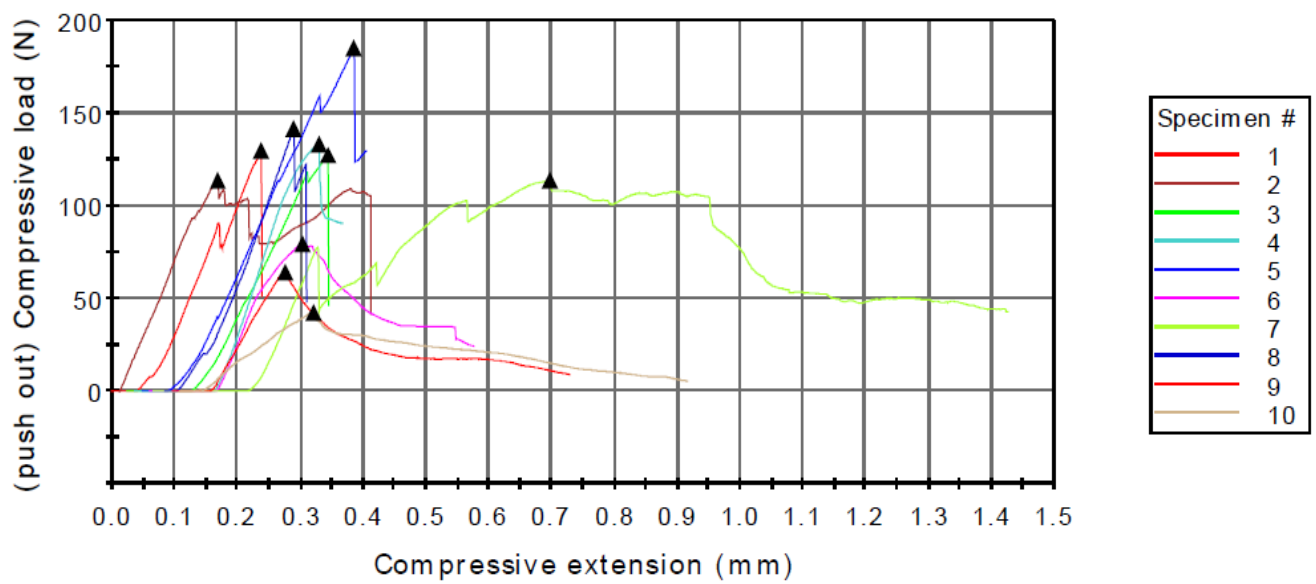

Fig. 3. Maximum load applied on the control group.

TABLE 2. The maximum load applied to the specimens $(\mathrm{N})$ and the calculated shear bond strength (MPa).

\begin{tabular}{lccc}
\hline Shear bond strength with exposure to radiation & $\begin{array}{c}\text { Shear bond strength with no exposure to radiation } \\
\text { (control group) }\end{array}$ \\
\hline Newton (N) & MPa & Newton (N) & MPa \\
\hline 125.5 & 6.7 & 130 & 6.9 \\
114.8 & 6 & 113.8 & 6.08 \\
158.5 & 8.4 & 127.3 & 6.75 \\
61.3 & 3.25 & 133.7 & 7.09 \\
49.9 & 2.64 & 185.2 & 9.8 \\
150.8 & 8 & 79.42 & 4.2 \\
43.7 & 2.31 & 113.7 & 6.03 \\
35.4 & 1.87 & 142 & 7.53 \\
86.6 & 4.59 & 64.3 & 3.4 \\
60.7 & 3.22 & 42.9 & 2.27 \\
\hline
\end{tabular}

TABLE 3. The shear bond strength mean value in MPa.

\begin{tabular}{lccc}
\hline Groups & $\begin{array}{c}\text { Samples exposed to } \\
\text { radiation }\end{array}$ & $\begin{array}{c}\text { Samples not exposed to } \\
\text { radiation } \\
\text { (control group) }\end{array}$ & $\begin{array}{c}\text { t-test } \\
\text { P-value }\end{array}$ \\
\hline Mean \pm SD & $4.69 \pm 2.41$ & & 1.26 \\
\hline
\end{tabular}

\section{Discussion}

Patients suffering from carcinomas are subjected to specific radio-therapeutic treatment that could alter the nature of the oral environment, change the oral flora and reduce the salivary flow; this could finally lead to increasing the chance of developing caries at the neck of the teeth (Toljanic et al., 1984). The increased risk for the development of rapid, rampant carious activity is well known as radiation caries. The lesions could develop four weeks after completion of the radiotherapy and affect unusual areas of the teeth, such as the lingual surface, incisal edges and cusp tips. (Ghasempour et al., 2009). Such patients, suffering multiple carious lesions, could not tolerate stressful, long chair -side restorative actions, however esthetic adhesive restorative materials could be the solution for many conditions. A newly introduced self 
-adhesive material eliminated the need to a separate etching and bonding step that was considered a technique sensitive and time consuming procedure (Frankenberger et al., 2000). Such a new technique could be beneficial for patients who could not endure long operative procedures.

Esthetic flowable restorative materials were recommended in restoring several cervical lesions such as class $\mathrm{V}$ and other non- carious lesions (Owen et al., 1998). Vertise-flow was marketed as an easy and comfortable esthetic restorative material for both the patient and the operator.

The self-adhesive property of Vertise Flow is based on the adhesive monomer glycerol phosphate dimethacrylate (GPDM), this functional monomer etches the enamel and the dentin. The $\mathrm{pH}$ of the material stated by the manufacturer is (1.9), thus it interacts with the dentin substrate in a manner similar to a mild self-etch adhesive (Tay et al., 2000). Also, it contains HEMA (hydroxyethyl methacrylate) to enhance wetting and resin penetration in dentin, due to its inherent hydrophilic nature. Comparing the shear bond strength of the Vertise Flow to other all-in-one adhesive systems, Vertise Flow recorded the lowest shear bond strength and the reason for such result was referred to the viscous nature of the material and lacking a solvent when compared to other test groups which could have impaired the wettability (Vichi et al., 2010, 2013).

Since ionizing radiation could induce a significant change in metallic and non metallic materials, the composite resin restoratives physical and mechanical properties could be influenced. This study was conducted to test the shear bond strength of this self-adhering flowable composite resin material when exposed to therapeutic dose of gamma radiation. The exposure of the polymers to the ionizing radiation could result in changes in the optical, mechanical and electrical properties. Such interaction could be manifested in reducing the water sorption and reduced solubility of some tooth colored restoratives (Von Fraunhofer et al., 1989).

The results of the current study showed that there was an insignificant decrease in the shear bond strength when the irradiated specimens were compared to the control group. This goes with the results of Naves et al. (2012). It was found that gamma radiation had a negative effect on the bond strength when the restorative procedure was carried out after radiation therapy. However, this was in contrast to Galetti et al. (2014), who stated that head and neck radiotherapy did not affect the dentin bond strength.

The variation in the bond strength could be attributed to the fact that the substrate was influenced by radiation and so was the created hybrid layer. It was reported that using 60 Gy gamma radiation altered the inter-prismatic structure of the human enamel, induced obliterated dentinal tubules of the dentin as well as fragmentation of the collagen fibers (Guenka et al, 2014)

Gamma radiation has greater penetration power and intensity than those of the visible light curing used in curing the resin material (Selman, 1980). This could influence the degree of conversion of the polymeric resin and was expressed in a significantly improved wear resistance of the light cured resin composite (El-Maghraby et al., 2005). Yet, it was stated that increasing the degree of conversion might result in a very brittle material. Vertise Flow contained an acidic resin which absorbs more water than neutral resins, for it was reported that Vertise Flow could demonstrate hygroscopic expansion than UDMA-based polymers (Labella et al, 1999). However, the water sorption of the irradiated resin composite materials was decreased when compared to non-irradiated ones (Von Fraunhofer et al., 1989). In the same manner, gamma radiation could have influenced the tested material due to the higher water content through HEMA included in its composition when compared to other polymers. Yet, the effect was not detrimental to the extent that induce a significant decrease in the shear bond strength.

\section{Conclusion}

According to the limitations of this study, the shear bond strength of the restored teeth with self-adhesive resin composite was not negatively affected by exposure to therapeutic doses of gamma radiation.

However, further investigations are recommended to study the effect of the therapeutic gamma radiation on the chemical composition and degree of conversion of the self-adhesive restoratives as well as for the color stability.

\section{References}

El-Maghraby, E., Badr, N. and Mahmoud, E. (2005) Effect of $\gamma$ radiation on selected mechanical properties of tooth- coloured restorative materials. Egyptian Dental Journal, 51(April), 805-818. 
Frankenberger, R., Kramer, N. and Petschelt, A. (2000) Technique sensitivity of dentin bonding: Effect of application mistakes on bond strength and marginal adaptation. Operative Dentistry, 25, 324-330.

Galetti, R., Santos-Silva, A.R., Antunes, A.N., Alves, Fde A., Lopes, M.A. and de Goes, M.F. (2014) Radiotherapy does not impair dentin adhesive properties in head and neck cancer patients. Clinical Oral Investigation, 18(7), 1771-8.

Ghasempour, M., Ahmadpour-Kacho, M. and Sheikhi, S. (2009) Dental caries in pre-term and low birth weight children and related factors. The Journal of Contemporary Dental Practice, 10(4), 51-58.

Guenka, L., Harley, P., Bezerra, F. and De Queiroz, S. (2014) Radiation therapy alters microhardness and microstructure of enamel and dentin of permanent human teeth. http:// dx.doi.org/doi:10.1016/j.jdent.2014.05.011.

Labella, R., Lambrechts, P., Van Meerbeek, B. and Vanherle, G. (1999) Polymerization shrinkage and elasticity of flowable composites and filled adhesives. Journal of Dental Materials, 15(2), 128-137.

Naves, L., Novais, V., Armstrong, S., Sobrinho, L. and Soares, C. (2012) Effect of gamma radiation on bonding to human enamel and dentin. Support Care Cancer, 20, 2873-2878.

Owens, B., Halter, T. and Brown, D. (1998) Microleakage of tooth-colored restorations with a beveled gingival margin. Quintessence International, 29(6), 356-361.

Selman, J.(1980) "The Fundamentals of X-ray and Radium Physics", $6^{\text {th }}$ ed. Springfield, Illinois, Bannerstone House.
Strong, M., Wang, C. and Clarck, J.(1986) "Cancer of the Head and Neck".Ca manual $7^{\text {th }}$ ed. Newyork, Amercian Cancer Society, app. pp. 132-133.

Tay, F.R., Sano, H., Pashly, E.l. and Pashly, D. (2000) An ultrastructural study of the influence of acidity of self-etching primers and smear layer thickness on bonding to intact dentin. Journal of Adhesive Dentistry, 2(2), 83-98.

Toljanic, A. and Saunders, W. (1984) radiation therapy and management of irradiated patient. The Journal of Prosthetic Dentistry, 52(6), 852-858.

Vichi, A., Goacci, C. and Ferrari, M.(2010)Clinical study of the self adhering flowable composite resin Vertise Flow in class I restorations: Six month follow up. International Dentistry South Africa; 12(1), 14-24.

Vichi, A., Margvelashvili, M., Goracci, C., Papacchini, F. and Ferrari, M. (2013) Bonding and sealing ability of a new self-adhering flowable resin in class I restorations. Clinical Oral Investigations, 17, 1497-1506.

Von, Fraunhofer, J., Curtis, P., Sharma, S. and Farman, A. (1989) The effect of gamma radiation on the properties of composite restorative resins. Journal of Dentistry, 17, 177-183.

Xie, H., Zhang, F., Wu, Y., Chen, C. and Liu, W. (2008) Dentin bond strength and microleakage of flowable composite, compomer and glass ionomer cement. Australian Dental Journal, 53(4), 325-331.

(Received 5 / 10 / 2017; accepted 10/ 2 / 2018) 


\footnotetext{
تأثير أشعة جامـا على قوة الر ابط القصي لحثوات مركب الراتين ذاتي الألتصاق والقابل للانسياب أنساب

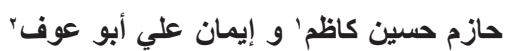

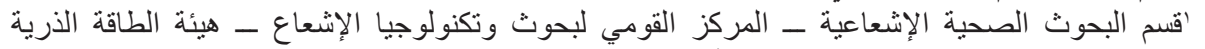

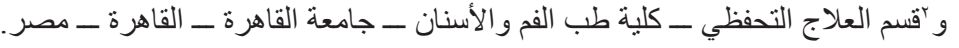

الهذف من الدراسة: اجري هذا البحث بهدف در اسة تأثثر التعرض لأشعة جاما على (Vertise-Flow) حشوات

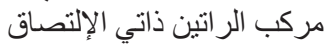

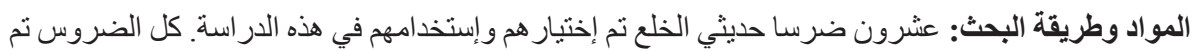

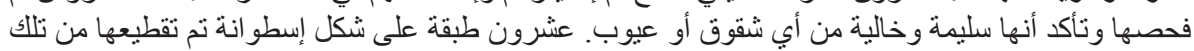

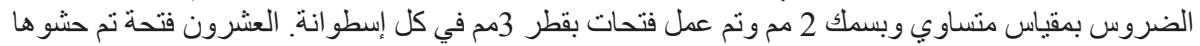

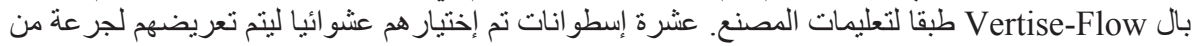

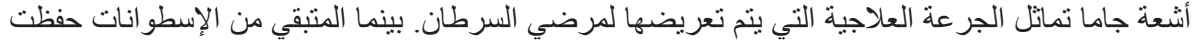
كمجمو عة ضابطة .

كل عينة تم إختبار ها بالتحميل الضابط بإستخدام ماكينة قياس الخامات بواسطة الكمبيوتر بتحميل قدرة

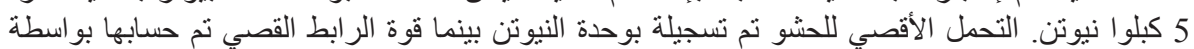
الميجاباسكال.

النتائج : وجد أن قوة الر ابط القصي لمركب الر اتين ذاتي الإلتصاق قد انخفضت عند التعرض للجر عة العلاجية لأشعة جاما ولكن هذا الإنخفاض كان بقدر غير ملحوظ أحصائيا.

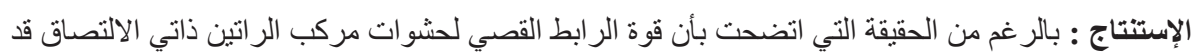

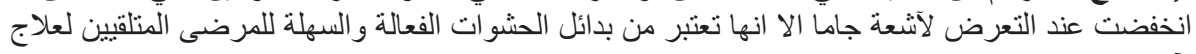
بآثنعة جاما.
} 